\title{
DE MALEISCHE HANDSCHRIFTEN DER LEIDSCHE BIBLIOTHEEK.
}

Als inleiding tot de hierachter volgende beschrijving der Maleische handschriften, die zich op de akademische bibliotheek bevinden, mogen enkele opmerkingen voorafgaan, zoo over het zamenstel van mijn catalogus, als over de Maleische letterkunde in het algemeen.

De eerste hoofdafdeeling, de Poëzie, heb ik onverdeeld gelaten, omdat het geringe aantal nommers eene splitsing onnoodig en dus ook niet wenschelijk maakte.

De tweede daarentegen, de werken in Proza, heb ik verdeeld in tien hoofdstukken. I bevat de rechtsgeleerde werken en wel A die over inlandsch, B die over Mohammedaansch recht handelen. Hiermede is niet bedoeld, dat A in 't geheel geen Mohammedaansche elementen zou bevatten; maar laat men de bromnen van het inlandsche recht ter zijde, dan staat $\mathrm{A}$ als burgerlijk en plaatselijk tegen $\mathrm{B}$ als godsdienstig en algemeen recht over. Onder II, de Mohammedaansche theologie, begrijp ik de werken, die in tegenoverstelling met I. B over dogmatiek, niet over practische theologie handelen, zoo ook de sectarische geschriften. De hoofdstukken III en IV verklaren zich zelf. Onder $\mathrm{V}$ heb ik bijeengevoegd de Mohammedaansche legenden en de dogmatische voorstellingen, die in den Koran of in de geschiedenis van Mohammed en die der oude heiligen van den Islam haren grond hebben, alsmede de verhalen en anecdoten uit de geschiedenis der Arabische kalifen, zoowel omdat het moeijelijk is, overal de juiste grens te. stellen, als ook omdat zij op het punt hunner aansluiting aan Mohammedaansche geloofswaarheden veelal overeenkomen. Hoofdstuk VI bevat al, wat de inlanders ons als geschiedenis hebben meegedeeld; hoofdstuk VII de Indische, Mohammedaansche, Javaansche en Maleische heldensagen. In VIII heb ik bijeengebracht, wat als Oostersche 
vertellingen een voornaam element van de Maleische literatuur uitmaakt. Ik versta daaronder vertellingen, zoo als de Arabische nachtvertellingen en dergelijke. Daaronder zijn kleine verhalen uit grootere verzamelingen, die, wanneer deze bekend waren, als fragmenten van zulke verzamelingen hare plaats onder IX zouden moeten hebben. Ook zouden sommige er van onder VII moeten gebracht worden, wanneer het bleek, dat onder den naam van den held een der helden van de sage verborgen was. Eindelijk kunnen er onder schuilen, die onder $\mathrm{V}$ zouden behooren geplaatst te worden, indien het Arabisch origineel door den verteller zoodanig verbasterd was, dat de strekking van het verhaal er geheel bij was uit het oog verloren. Men vindt dus de Arabische verhalen meestal in V, de Indische en andere Oostersche in dit hoofdstuk VIII, waarbij men er evenwel op te letten heeft, dat de oorspronkelijke Arabische taal dier verhalen geen criterium is voor hun Arabischen oorsprong; trouwens iedereen weet, dat de Arabische nachtvertellingen bijvoorbeeld op een niet Arabischen stam geënt zijn. Hoofdstuk IX bevat de fabelen en zedekundige werken, de eersten omwerkingen van Indische of Arabische fabelverzamelingen, de anderen insgelijks verzamelingen van verhalen, die even als de eerstgenoemden eene zedelijke of althans practische strekking hebben. Onder X breng ik eindelijk alles, wat zoo op zich zelf staat, dat het, terwijl het in geen der vorige hoofdstukken past, bijna evenveel nieuwe hoofdstukken zou noodig maken, als er nommers in zijn, of ook, wat ik om mijne onvolledige bekendheid met den inhoud nog niet onder eene bepaalde rubriek durf rangschikken.

Sommige van deze hoofdstukken zouden ook ter verdeeling van de werken der eerste afdeeling, de Poëzie, kunnen strekken. Enkele zouden tot de verhalen van V of VIII kunnen gebracht worden, andere als leerdichten onder $1 \mathrm{X}$, of als geschiedkundige feiten behandelende onder VI, of als helden bezingende onder VII; zelfs onder II zouden er te brengen zijn. Maar voor de poëzie alleen zouden altoos overblijven de pantoens en minneliederen.

In een catalogus van Maleische werken is het korte overzicht van den inhoud een noodzakelijk bibliographisch vereischte, omdat men uit den inhoud dikwijls alleen kan weten, of twee boeken dezelfde zijn. Op den titel, dien men vóór in het boek vindt opgegeven, moet men nooit te zeer vertrouwen. Men zal 
daarvan in dezen catalogus merkwaardige bewijzen vinden (zie bijv. no. 1729). Van den anderen kant moet men niet te spoedig uit een verschil van redactie, vooral van den aanhef, tot een verschil van werk besluiten. Inzonderheid bij de verhalen, en niet het minst bij de poëtische, zijn de afwijkingen van lezing dikwijls aanmerkelijk, zoodat hier het bezit van een aantal handschriften van hetzelfde werk niet in die mate begeerlijk is ter vaststelling van een zuiveren tekst, als dit bij onze klassieke talen het geval pleegt te zijn.

Deze overzichten zullen tevens den oningewijde eenigzins nader met den aard der Maleische literatuur bekend maken, hetgeen ook deze geheele catalogus moge bevorderen. Men meene niet, dat onze verzameling te klein zou zijn, om tot grondslag van zulk eene beschouwing te kunnen dienen. Noch in Londen, noch in Parijs, de eenige plaatsen in het buitenland, waar, voor zoo ver mị bekend is, verzamelingen van Maleische handschriften van eenig belang gevonden worden, zijn er zooveel, als wij er hier hebben. In de bibliotheek van het Britsch Museum, waar de handschriften zijn, die aan J. Crawfurd toebehoord hebben, zijn 24 nommers; in die van het Indian Office 25; grootendeels van J. Leyden afkomstig; voorts bevat de collectie van Raffles in de bibliotheek der Royal Asiatic Society er 90, te zamen ruim 140 nommers, terwijl er te Parijs, volgens een geschreven catalogus in mijn bezit, 58 zijn, waaronder echter zeer vele copieën van handschriften in Engeland. En wij hebben thans juist 160 nommers. $\mathrm{Nu}$ weet $\mathrm{ik}$ wel, dat die nommers niet alle even zwaar wegen, maar de hoofdzaak is hier, dat wij, onze verzameling vergelijkende met de andere, gerust kunnen zijn, dat zij ons toelaat een oordeel over de Maleische literatuur te vellen.

Het moet ons, bij het doorloopen van onzen catalogus, aanstonds treffen, hoe weinig oorspronkelijks de Maleische literatuur bevat. Van I is het tweede gedeelte Mohammedaansch recht en II is geheel Mohammedaansche theologie, beiden wel in het Maleisch geschreven, maar óf uit Arabische werken geput, zoo al niet geheel vertaald, óf althans een uitvloeisel van Arabische schoolgeleerdheid. De Christelijke theologie en de Mohammedaansche legenden in III en V zijn evenmin uit Maleische bronnen gevloeid. De heldensagen van VII zijn, op eene enkele uitzondering na, navolgingen van. Indische en Perzische origineelen. Ook in de werken, die tot IX behooren, is niet veel meer Maleisch dan 
de taal, iets dat voor een groot deel ook op die van VIII toepasselijk is, al kan men niet telkens de bron aanwijzen, waaruit ieder verhaal geput is. Oorspronkelijke Maleische werken hebben wij dus slechts onder I. A, IV, VI en X te zoeken, en verder in de eerste afdeeling, de poëtische literatuur, waarop evenwel een groot deel, van hetgeen omtrent het proza gezegd werd, mede toepasselijk is.

Toch zou ik meenen, dat het grootste deel der poëtische producten oorspronkelijk is. Der poëtische producten! men mag den Muzen wel offeren. als men zich hier van het woord poëzie bedient. Rijmelarijen zijn het, die men of als rariteiten verzameld of als curiosa bewaard heeft. $1 \mathrm{k}$ heb die Maleische pantoens nog lang trachten te verdedigen en er den stempel der onvervalschte natuur in willen terugvinden. Maar ik moet het opgeven. Niet dat die onvervalschte natuur er in ontbreken zou; valsch is natuur nooit en natuur zijn ze geheel; maar ik had er eene andere natuur in verwacht, eene natuur zoo als die der ongekunstelde volkspoëzie bij volken van onzen stam, eene natuur, waarvoor ons hart zich opent en wij sympathie $\bullet$ kunnen gevoelen. Aan het bestaan eener andere natuur had ik niet gedacht. Ik heb er met één woord poëzie, poëtisch gevoel, in gezocht, onder welken vorm dan ook, maar ik heb die in Maleische gedichten niet gevonden. Als gij meent, dat de Maleijer poëtisch is, zoo als in de Bidasari, van welk gedicht de heer van Hoëvell ons in het 19e deel der. Werken van het Batav. Genootschap den tekst en eene vertaling gegeven heeft, dan kunt gij er op aan, dat hier navolging in 't spel is. ${ }^{1}$

1 Ik houd die Sjair Bidasari voor niets anders dan eene berijmde wajangvertelling uit deu Engelschen tijd, toen er naar het artikel inlandsche literatuur zooveel vraag was. In dien tijd zijn mijns inziens meer literarische producten ontstaan, hetzij Sjairs, zooals de Bidasari en Kin Těmboehan, of zoogenaamde historische werken, inzonderheid zulke, die Javaansche geschiedenissen bevatten, waarschijnlijk ook wel de Maleische bewerking van de Javaansche Pandsji-verhalen en andere. Reeds werd op het gebied der antiquiteiten eene ontdekking gedaan, die getuigt, hoe de Javanen hun voordeel weten te doen met de liefhebberijen der Europeanen; men is namelijk eens een fabriekant van antieke beeldjes op 't' spoor gekomen. (Zie Dr. C. Leemans, Over metalen beeldjes op Java, in Verhalen en Mededeelingen der Kon. Akademie van Wetensch. Letterkunde III p. 187.). Welnu, zou een ijver als die, waarmede Raftles inlandsche handschriften verzamelde, ook niet iets dergelijks ten gevolge kunnen gehad hebben? Zie hier, wat de bekende schrijver Abdoellah, die klerk bij Raffles was, in zijne autobiographie van dien ijver verhaalt. $\mathrm{Na}$ verteld te hebben, hoe Raftles al het mogelijke verzamelde, wat de drie rijken der natuur voortbrengen, gaat hij aldus voort: "En ik weet niet, hoeveel honderde soorten van boeken men toen 
Wilt gij eene proef van het poëtisch gevoel der Maleijers? Aan het slot der geschiedenis van Rama, oorspronkelijk het welbekende Indische Ramájana, sneuvelt een der zonen van Ráwana in een gevecht met genoemden held. De droefheid van den vader wordt op inderdaad treffende wijze geschilderd. Allen, zoo eindigt die beschrijving, hem zoo ziende jammeren, weenden met hem mede. En wat voegt nu de Maleische bewerker — of ik wil hopen, dat het slechts een overschrijver geweest is - er bij (waarbij men moet weten, dat Ráwana in de mythe voorgesteld werd met tien hoofden)? Welnu, op die treffende passage volgt dit: En sommigen lachten, toen zij al die tien monden van Ráwana zoo zagen praten! Dit laatste is echt Maleisch, het daaraan voorafgaande is slechts navolging. Wilt gij Maleische literatuur genieten? Laten ze u vertellen in gewoon proza. Dat doen ze soms op voortreffelijke wijze. Maar daarmee is dan ook alles van humne literatuur gezegd.

Want wat blijft er toch van die afdeeling proza, zoo als wij die in tien hoofdstukken verdeeld hebben, als oorspronkelijk Maleisch over. Het zesde hoofdstuk, de geschiedenis? Dit bevat echter alweder niets anders dan verhalen en anecdotes van dezen of genen vorst of held - zoo als het eenige echt Maleische heldenverhaal, de Hikajat Hang Toewah, ook niets anders is dan een zeer uitvoerig, maar onzinnig zamenraapsel van allerlei anecdotes, waarvoor eensdeels hunne geschiedboeken, anderdeels hunne van allerlei verhalen vervulde fantazie de stof geleverd hebben. Die

wel bracht; al de Maleische geschriften, sints onheugelijke tijden door hunne vooronders verzameld, brachten zij hem van alle kanten en verkochten zij hem, want zij kregen er goed geld voor en zij dachten er niet aan, of hunne nakomelingen ook dom zonden worden, door geen enkel boek meer te hebben, in hun eigen tal geschreven. De boeken, die hij zoo verzamelde, zullen een 360 geweest zijn, behalve nog de gedichten, en er waren ook nog andere, die hij geleend had en die hij liet afschrijven door vier of vijf klerken, die niets anders deden." Toen Raffles naar Europa vertrok, was het wederom Abdoellah, die zijne manuscripten inpakte en die ons vertelt, dat er een 300 ingebonden waren en buitendien nog eene groote menigte oningebonden of in rollen en losse vellen, zoodat hij er drie kisten van zes voet lang mee vulde. Dat waren alle Maleische handschriften. Een paar andere kisten bevatten de manuseripten in het Javaansch en in andere talen van den Archipel. $W_{i j}$ weten, dat zij alle verloren gingen bij den brand van het schip, waarmee Raffles naar het vaderland zou terugkeeren. Wanneer nu Abdoellah elders vertelt, dat Raffles altijd gaf, wat men vroeg, hoe groot de som ook was, dan kan men niet nalaten te denken, dat er onder al die boeken vele zullen geweest zijn, die hun ontstaan aan deze gelegenheid te danken hadden? 
geschiedboeken dus, hoezeer ook met geslachtslijsten overladen, die doorgaans weinig geschiedkundige waarde hebben, behooren eigenlijk alweder tot de kategorie der verhalen. Eene kritische bewerking van de zoo geroemde Sĕdsjara-Mělajoe, waaruit Valentijn en Marsden en de enkele schrijvers over Maleische geschiedenis, die hen niet naschreven, hunne kennis geput hebben, zal onmiddellijk het chronologisch gebouw dier geschiedenis, dat schijnbaar op zuilen rust, aan wier hechtheid te weinig getwijfeld is, in puin doen vallen. Behalve die verhalen dus, hetzij dan geheel fictieve, hetzij zulke, die met de geschiedenis zamenhangen en van deze ook het gewaad dragen, biedt ons de Maleische literatuur op het gebied van het proza niets oorspronkelijks aan dan werken, die over waarzeggerij en inlandsche geneeskunst handelen (hoofdstuk IV, dat echter ook nog, zoo als bij eene inzage terstond blijken zal, verscheiden werken van vreemden oorsprong bevat) en enkele inlandsche wetten.

Eene tweede opmerking, die men maken zal, is, dat men te vergecfs naar namen van auteurs zoekt. En inderdaad, zondert men enkele schrijvers uit, wier namen en geschriften ons aanstonds aan Arabieren of althans afstammelingen van Arabieren doen denken, dan blijft er van auteursnamen al heel weinig over en bepaalt dit zich bijna tot die rijmelaars, die hun namen noemen, omdat zij zich aanspraak willen verwerven op dank of loon van een vermogenden Maecenas. Slechts de klerken schrijven dikwijls hunnen naam in de boeken, die zij overschreven; zoo komt men bij het doorzien van eene eenigszins uitgebreide collectie handschriften enkele namen tegen, die herhaalde malen terugkeeren en die in een wedstrijd voor calligraphie geen kwade figuur zouden maken. Maar zulke namen hebben toch somtijds nog eene andere waarde. Zoo liet bijvoorbeeld de uitgever van het gedicht Bidasari zich door het uitwendig voorkomen van een handschrift verleiden, om daaraan een hoogen ouderdom toetekennen. Het jaar, waarin het boek werd afgeschreven, dat anders doorgaans pleegt opgegeven te worden, ontbrak ditmaal; daarentegen was de naam van den overschrijver vermeld. En zie, die overschrijver is een oude kennis, wiens naam ten bewijze strekt, dat het handschrift nagenoeg even oud is als een ander, dat volgens dien uitgever van zeer laten datum is. Zoo kunnen wij uit den naam van een bekend kopiïst den ouderdom van het handschrift opmaken, zelfs waar hij den datum vergat optegeven. Maar die datum leert ons nog slechts den ouderdom 


\section{DE MAL. HANDSCHRIFTEN DER LEIDSCHE BIBLIOTHEEK.}

van het handschrift, niet den leeftijd van den schrijver. Evenzoo kan ook de vermelding der plaats, waar eenig handschrift geschreven is, van belang zijn, doch altoos slechts voor de waardeering van het handschrift alleen.

Zoo zijn wij dus ter verkrijging van eenige meerdere kennis van den leeftijd en het vaderland der auteurs aangewezen op den inhoud der boeken zelve. Bij alle fictieve verhalen of ook maar zulke, die geheel buiten den leeftijd en de omgeving van den schrijver liggen, is het hoogst onwaarschịnlijk, dat de auteur zijn leeftijd op de een of andere wijze verraden zou. Maar wanneer de auteurs onbekend blijven, terwijl toch hunne werken blijven voortleven, is dit een bewijs, dat die werken de uitdrukking zijn van den volksgeest, dat het volk zich die als 't ware heeft toegeeigend en de auteurs vergeten, door wier mond werd uitgesproken, wat slechts een toevallig eigendom van hen was. Zoo zijn ook de sprookjes bij ons altemaal volkssprookjes, volksliteratuur. In zulk een toestand der beschaving, want de literatuurgeschiedenis is cultuurgeschiedenis, zijn er geen individuen, die zich losrukken van de menigte, is er geen inspiratie, is er geen invloed van enkele geesten op het volk, is er geen vooruitgang. De oingang met de Europeanen heeft het Maleische ras als zoodanig nog niets veranderd. De werken der Maleijers van voor twee honderd jaar of nu verschillen in innerlijke waarde nog geen zier. Eerder is de algemeene toestand hunner literatuur achteruitgegaan, want de Arabieren, die in goed Maleisch "omdat het volk geen Arabisch verstond," zoo als zij meermalen zeggen, werken schreven zoo als de Bostanoéssalatina en de Tadjoéssalatina (ik vooronderstel, dat ook dit werk oorspronkelijk beter is opgesteld, dan het later is uitgegeven), zijn uitgestorven en door geen andere goede schrijvers vervangen. 1 Onze tijd leverde alleen Abdoellah van Malakka, die reeds in 1854 overleed.

Maar ik zou vergeten, dat ik een catalogus schrijf en voeg hier dus nog slechts de opmerking bij, dat de handschriften in ieder der hoofdstukken van mijne lijst gerangschikt zijn naar de volgorde der nommers, waarmede zij in de akademische bibliotheek genommerd zijn.

J. Pijnappei, Gz.

1 No. 1724. $a$. bijv. is ook van een Arabier, maar welk een onderscheid van taal met de ondere schrijvers! 